\title{
KURIOS
}

(Jurnal Teologi dan Pendidikan Agama Kristen)

Vol. 2, No. 1, Oktober 2014 (46-56)

ISSN 2406-8306 (print)

http://www.sttpb.ac.id/e-journal/index.php/kurios

\section{Teori Psikologi Perkembangan Erik H. Erikson dan Manfaatnya Bagi Tugas Pendidikan Kristen Dewasa Ini}

\author{
Yeni Krismawati \\ Sekolah Tinggi Teologi Pelita Bangsa Jakarta
}

\section{Pendahuluan}

Perilaku seseorang tidak hanya dipengaruhi oleh dorongan dari dalam dirinya Perkembangan tersebut ditentukan juga oleh kompleksitas faktor eksternal. Interaksi dengan orang-orang atau kelompok disekitarnya merupakan salah satu faktor ekternal yang mempengaruhi proses pembentukan perilaku. Interaksi tersebut bahkan menjadi salah satu kebutuhan dasar manusia mengingat bahwa seseorang tidak dapat hidup sendiri tanpa orang lain (Maslow). John Bowlby juga menjelaskan kebergantungan terhadap orang lain sudah dirasakan seseorang sejak masih bayi sebagai perilaku penyesuaian sosial paling awal melalui kelekatannya dengan orangtua. Penyesuaian sosial akan terus berlangsung hingga usia dewasa yang terbentuk melalui proses belajar dari sesamanya (Albert Bandura).

Pentingnya pengaruh sosial dinyatakan dalam Alkitab melalui kebutuhan Adam untuk berinteraksi dengan lingkungan dan orang lain sebagai penolong (Kejadian 2:18-25). Tokohtokoh dalam Alkitab baik yang berkarakter positif atau negatif memiliki kaitan erat dengan pengaruh orang-orang penting disekitarnya (Misal: Peran Musa pada Yosua, pengaruh Izebel terhadap Ahab, Arti kehidupan Tuhan Yesus bagi para murid, pengaruh Louis dan Eunike kepada Timotius). Agar menghasilkan perilaku yang baik, perlu adanya usaha kritis menyikapi setiap interaksi sosial mengingat perilaku buruk lebih cepat mempengaruhi kehidupan seseorang (I Korintus 15:33). Sebaliknya, pangaruh orang-orang dekat dalam keluarga serta lingkungan yang mendukung, membentuk perilaku yang kuat dan stabil (II Timotius 1:5).

\section{Perkembangan Psikososial Erik H. Erikson}

Salah satu ahli yang mendasari teorinya dari sudut sosial ialah Erik H. Erikson dengan menyebut pendekatannya "Psikososial" atau "Psikohistoris". Erikson berusaha menjelaskan bahwa ada hubungan timbal balik antara pribadi dan kebudayaan sampai orang tersebut 
menjadi dewasa. Disini terlihat bahwa lingkungan hidup seseorang dari awal sampai akhir dipengaruhi oleh sejarah seluruh masyarakat karena perkembangan relasi antara sesama manusia, masyarakat serta kebudayaan semua saling terkait. Itu berarti tiap individu punya kesanggupan untuk menyesuaikan diri dengan lingkungan yang senantiasa berkembang dari orang-orang atau institusi supaya ia bisa menjadi bagian dari perhatian kebudayaan secara terus-menerus.

Erikson berusaha menemukan perkembangan psikososial Ego melalui berbagai organisasi sosial dalam kelompok atau kebudayaan tertentu. Ia mencoba meletakkan hubungan antara gejala psikis, edukatif dan gejala budaya masyarakat. Dalam penelitiannya, Erikson membuktikan bahwa masyarakat atau budaya melalui kebiasaan mengasuh anak, struktur keluarga tertentu, kelompok sosial maupun susunan institusional, membantu perkembangan anak dalam berbagai macam daya Ego yang diperlukan untuk menerima berbagai peran serta tanggung jawab sosial.

\section{Biografi Erikson}

Erik Erikson dilahirkan pada 15 Juni 1902 di Danish dekat kota Frankfurt, Jerman. Sejak lahir ia sudah tidak punya ayah karena orangtuanya telah berpisah sehingga Erik dibesarkan oleh ibunya. Mereka pindah ke Karlsruhe lalu ibunya menikah dengan dr. Homburger yang berkebangsaan Jerman, ayah kandung Erik sendiri orang Denmark. Saat itu Erik berusia 3 tahun dan pada awal remaja ia mengetahui bahwa nama sisipan diberikan karena Homburger adalah ayah tirinya. Erik tidak dapat menyelesaikan sekolah dengan baik karena ketertarikannya pada berbagai bidang khususnya seni dan pengetahuan bahkan ia sempat berpetualang sebagai artis dan ahli pikir di Eropa tahun 1920-1927. Identitas religius awalnya ialah Yudaisme sebagai warisan keluarga tetapi Erikson kemudian memilih Kristen Lutheran.

Pada tahun 1927 sampai tahun 1933, Erikson bergabung dengan lembaga pendidikan Psikoanalisis Sigmund Freud's untuk mengajar anak sehingga ia berkenalan dengan psikoanalisa Frued melalui Ana Freud. Tahun 1929 Erik menikah dengan gadis Kanada, Joan Serson. Karena ketertarikannya pada dunia anak dan pendidikan, Erikson melanjutkan studi non-formal sampai akhirnya menjadi profesor dan mengajar tetap di California sejak 1939. Ia mendirikan klinik analisis anak, menekuni dunia pendidikan, serta menulis buku-buku. Erikson telah menemukan Identitas baru dengan multiragamnya, kemudian ia meninggal pada tahun 1994. 


\section{Sumber dan Dasar Teori Erikson}

Latar belakang keluarga, pendidikan, agama, kebangsaan serta profesi yang sempat mengacaukan identitasnya, berhasil mendorong Erikson menciptakan formulasi konseptual tentang terjadinya identitas. Setiap orang belajar melalui orang-orang yang berpengaruh atas dirinya melalui peran relasi-relasi sosial yang terjadi secara terus-menerus. Keterlibatan Erikson dengan lembaga pendidikan Sigmund Freud's menjadikannya banyak belajar mengenai teori Psikoseksual. Itu sebabnya Erikson dikategorikan sebagai ahli Neo-Freudian karena pandangannya merupakan perluasan dari teori Freud.

\section{Persamaan Antara Teori Erikson dan Psikoseksual Freud}

Sebagai tokoh yang lebih suka disebut “psikolog Ego pasca-Freudian”, Erik mempunyai beberapa kesamaan pandang dengan Freud sebagai panutannya:

1. Sebagaimana Freud, Erik melihat realitas serta urutan semua tahap dalam perkembangan setiap individu sebagai hal yang tidak berubah karena sudah ditentukan sebelumnya.

2. Erik juga mengakui adanya struktur kepribadian triganda manusia yang terdiri dari tiga komponen yaitu Id, Ego dan Superego.Pengakuan terhadap akar dan dasar seksual serta biologis sebagai kecenderungan motivasional dan kepribadian selanjutnya.

3. Menyetujui bahwa rencana dasar kepribadian manusia ditandai oleh berbagai hal tetap seperti: konflik traumatis yang mungkin berhubungan dengan menyusui anak, pembuangan air seni atau feses, penegasan diri falis pada anak laki-laki maupun sifat mudah menerima pada anak perempuan.

\section{Perbedaan Pendapat Antara Erikson dan Freud}

Sekalipun salah satu sumber yang dipakai Erikson untuk menciptakan teorinya adalah berdasarkan pandangan Freud, namun tetap ada perbedaan-perbedaan diantara keduanya, yaitu:

1. Psikoseksual Freud berdasarkan pendekatan perkembangan afektif, irasional, dan naluriah (seksualitas dan agresi) manusia sedangkan Erikson menciptakan pendekatan psikososial dari hasil penelitiannya terhadap psikoanalisis Freud yang diperluas.

2. Menurut Erikson, Ego atau aspek pkikologis adalah struktur kepribadian manusia yang relatif otonom, berkembang secara sosial dan adaptif sehingga mendorong perkembangan manusia. Adapun Freud berpendapat bahwa Id menjadi daya dorong bagi segala perkembangan.

3. Freud mengemukakan gambaran manusia sebagai pribadi yang suram dan pesimistis dimana sikap positif hanya sebagai penyamaran dari dimensi negatif. Tanggapan Erikson 
adalah bahwa ia melihat gambaran manusia sebagai pribadi yang optimis dan menggairahkan.

4. Solusi yang ditawarkan Freud dalam memecahkan masalah ialah mengembalikan fenomena psikis kepada trauma awal yang terjadi pada masa lampau yang dialami seseorang pada masa anak. Sedangkan pemikiran Erikson mengarah pada masa depan serta daya-daya penyembuhan yang sedang berpengaruh dalam setiap manusia.

5. Freud memfokuskan teorinya berdasarkan daya-daya naluri infra-psikis yang berada di dalam diri setiap orang. Erikson berpendapat bahwa perspektif psikososial yang memperhitungkan faktor ekstern menjadi aspek penting yang ikut menentukan perkembangan dan pembentukan identitas seseorang.

6. Berkaitan dengan pengujian teori, Erikson adalah psikoanalis anak pria yang pertama dimana teorinya teruji melalui kontak langsung dengan anak-anak khususnya lewat permainan. Sedangkan Freud tidak pernah secara langsung dan sistematis menangani atau mengobati anak kecil sehingga teorinya lebih berdasarkan data empiris yang diperolehnya sendiri.

\section{Tahap-tahap Perkembangan Psikososial}

Erikson berpendapat bahwa sepanjang sejarah hidup manusia, setiap orang mengalami tahapan perkembangan dari bayi sampai dengan usia lanjut. Perkembangan sepanjang hayat tersebut diperhadapkan dengan delapan tahapan yang masing-masing mempunyai nilai kekuatan yang membentuk karakter positif atau sebaliknya, berkembang sisi kelemahan sehingga karakter negatif yang mendominasi pertumbuhan seseorang. Erikson menyebut setiap tahapan tersebut sebagai krisis atau konflik yang mempunyai sifat sosial dan psikologis yang sangat berarti bagi kelangsungan perkembangan di masa depan.

Delapan tahapan perkembangan tersebut sebagai berikut:

\section{Tahap I usia 0-2 tahun}

Pada masa bayi atau tahun pertama adalah titik awal pembentukan kepribadian. Bayi belajar mempercayai orang lain agar kebutuhan-kebutuhan dasarnya terpenuhi. Peran ibu atau orang-orang terdekat seperti pengasuh yang mampu menciptakan keakraban dan kepedulian dapat mengembangkan kepercayaan dasar. Persepsi yang salah pada diri anak tentang lingkungannya karena penolakan dari orangtua atau pengasuh mengakibatkan bertumbuhnya perasaan tidak percaya sehingga anak memandang dunia sekelilingnya sebagai tempat yang jahat. Pada tahap ini kekuatan yang perlu ditumbuhkan pada kepribadian anak ialah "harapan". 


\section{Tahap II, usia 2-3 tahun}

Konflik yang dialami anak pada tahap ini ialah otonomi vs rasa malu serta keraguraguan. Kekuatan yang seharusnya ditumbuhkan adalah "keinginan atau kehendak" dimana anak belajar menjadi bebas untuk mengembangkan kemandirian. Kebutuhan tersebut dapat terpenuhi melalui motivasi untuk melakukan kepentingannya sendiri seperti belajar makan atau berpakaian sendiri, berbicara, bergerak atau mendapat jawaban dari sesuatu yang ditanyakan.

\section{Tahap III, usia 3-6 tahun}

Anak pada tahap ini belajar menemukan keseimbangan antara kemampuan yang ada dalam dirinya dengan harapan atau tujuannya. Itu sebabnya anak cenderung menguji kemampuannya tanpa mengenal potensi yang ada pada dirinya. Konflik yang terjadi adalah

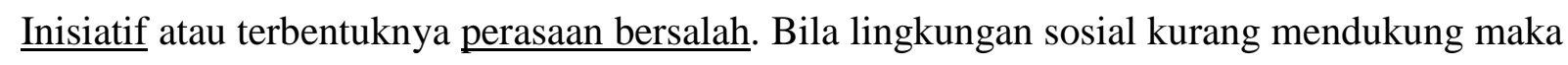
anak kurang memiliki inisiatif.

\section{Tahap IV, usia 6-12 tahun}

Konflik pada tahap ini ialah kerja aktif vs rendah diri, itu sebabnya kekuatan yang perlu ditumbuhkan ialah "kompetensi" atau terbentuknya berbagai keterampilan. Membandingkan kemampuan diri sendiri dengan teman sebaya terjadi pada tahap ini. Anak belajar mengenai ketrampilan sosial dan akademis melalui kompetisi yang sehat dengan kelompoknya. Keberhasilan yang diraih anak memupuk rasa percaya diri, sebaliknya apabila anak menemui kegagalan maka terbentuklah inferioritas.

\section{Tahap V, usia 12-20 tahun}

Pada tahap ini anak mulai memasuki usia remaja dimana identitas diri baik dalam lingkup sosial maupun dunia kerja mulai ditemukan. Bisa dikatakan masa remaja adalah awal usaha pencarian diri sehingga anak berada pada tahap persimpangan antara masa kanak-kanak dengan masa dewasa. Konflik utama yang terjadi ialah Identitas vs Kekaburan Peran sehingga perlu komitmen yang jelas agar terbentuk kepribadian yang mantap untuk dapat mengenali dirinya.

\section{Tahap VI, usia antara 20-40 tahun}

Pada tahap ini kekuatan dasar yang dibutuhkan ialah "kasih" karena muncul konflik antara keintiman atau keakraban vs keterasingan atau kesendirian. Agen sosial pada tahap ini ialah kekasih, suami atau isteri termasuk juga sahabat yang dapat membangun suatu bentuk persahabatan sehingga tercipta rasa cinta dan kebersamaan. Bila kebutuhan ini tidak terpenuhi, maka muncullah perasaan kesepian, kesendirian dan tidak berharga. 


\section{Tahap VII, usia 40-65 tahun}

Seseorang telah menjadi dewasa pada tahap ini sehingga diperhadapkan kepada tugas utama untuk menjadi produktif dalam bidang pekerjaannya serta tuntutan untuk berhasil mendidik keluarga serta melatih generasi penerus. Konflik utama pada tahap ini ialah generatifitas vs stagnasi, sehingga kekuatan dasar yang penting untuk ditumbuhkan ialah "kepedulian". Kegagalan pada masa ini menyebabkan stagnasi atau keterhambatan perkembangan.

\section{Tahap VIII, usia 65 tahun-kematian}

Pribadi yang sudah memasuki usia lanjut mulai mengalami penurunan fungsi-fungsi kesehatan. Begitu juga pengalaman masa lalu baik keberhasilan atau kegagalan menjadi perhatiannya sehingga kebutuhannya adalah untuk dihargai. Konflik utama pada tahap ini ialah Integritas Ego vs Keputusasaan dengan kekuatan utama yang perlu dibentuk ialah pemunculan "hikmat atau kebijaksanaan". Fungsi pengalaman hidup terutama yang bersifat sosial, memberi makna tentang kehidupan.

\section{Pembahasan}

\section{Manfaat Bagi Tugas Pendidikan Kristen Dewasa Ini}

Berdasarkan tahapan perkembangan Erikson, adanya kekuatan dan kelemahan karakter yang dominan saling mempengaruhi dari tahap satu kepada tahap berikutnya. Seseorang dapat menjadi dewasa melalui setiap proses perkembangan apabila berhasil mengembangkan sisi positif dari setiap konflik melalui kemampuannya untuk mengubah diri sendiri yang dipengaruhi oleh berbagai perubahan intern maupun peran orang-orang bermakna. Dikaitkan dengan peran pendidikan Kristen dalam keluarga, gereja, maupun sekolah, ada banyak manfaat yang dapat dikembangkan dari psikososial Erikson bagi pelayanan.

\section{Bagi Anak Usia 0-3 Tahun}

- Manfaat Bagi Pendidikan Keluarga

a) Orangtua khususnya ibu berperan penting dalam menumbuhkan harapan agar

$\checkmark$ anak percaya kepada Allah, orang lain dan lingkungannya melalui: Kelekatan yang diupayakan dengan memotivasi para ibu untuk meluangkan banyak waktu dan kasih sayang bersama anak.

$\checkmark$ Orangtua dapat mengkondisikan anak mengenal Allah melalui saat teduh pribadi, keluarga, atau dalam kebaktian di gereja. Menerapkan prinsip "shema" (Ul. 6:4-9) melalui cerita sebelum tidur. 
b) Usaha membentuk "kehendak" dapat ditumbuhkan melalui motivasi agar anak belajar melakukan kepentingannya sendiri atau diberi kebebasan menanyakan dan memperoleh jawaban atas sesuatu yang ia tanyakan.

c) Anak rentan terhadap penyakit sehingga orangtua penting untuk menjaga kesehatan anak karena perkembangan fisik mempengaruhi kemandirian anak.

d) Filter terhadap Baby Sitter sebagai salah satu orang berpengaruh yang perlu diperlengkapi demi mendukung pertumbuhan anak

- Manfaat Bagi Pendidikan di Gereja

a) Dalam rangka membentuk kepercayaan dasar anak kepada Tuhan, konsep ibadah lebih tepat ditanamkan bila anak bersama dengan orangtuanya mengikuti kebaktian bersama. Anak yang belajar melalui apa yang dilihat dan didengar dapat menyaksikan sendiri otoritas Allah atas keluarga. Dalam hal ini penting bagi gereja untuk menyediakan tempat duduk khusus mungkin dekat dengan pintu sehingga apabila sewaktu-waktu anak menangis, dapat segera keluar untuk ditertibkan.

b) Memperlengkapi keluarga muda melalui pelayanan khusus bagaimana membesarkan anak secara Kristen.

c) Bila gereja sudah mengadakan kebaktian Sekolah Minggu untuk usia Batita, penting mendorong orangtua atau pengasuhnya mendampingi anak selama kebaktian dengan tujuan mengulangi kembali pesan dari Firman Tuhan dalam rangka penguatan makna agar anak tidak "ragu" terhadap kebenaran yang telah diterima. Peran orang dekat untuk meyakinkan anak akan Firman Tuhan secara berulang-ulang sangat berarti (Maz. 78:5-6).

\section{Bagi Anak Usia 3-5 tahun}

- Manfaat Bagi Pendidikan Keluarga

Dalam rangka penguatan “inisiatif” orangtua sedapat mungkin menghindari kata "jangan begini/begitu.." melainkan memberi kesempatan agar anak menguji kemampuannya, misalnya mengambilkan minum untuk orangtua, dilibatkan untuk memimpin doa atau memuji Tuhan di rumah. Kepekaan orangtua melihat bakat dan minat anak dengan menyertakan anak mengikuti kursus tertentu atau penyediaan sarana bagi pengembangan bakat.

- Manfaat Bagi Pendidikan di Gereja

a. Menciptakan SM yang kreatif dengan melibatkan anak mengerjakan aktifitas, bermain atau menyanyi di depan dapat menumbuhkan inisiatif pada anak.

b. Membekali guru SM untuk memahami perilaku murid yang menyukai kebebasan mengekspresikan keinginannya sekalipun dalam kebaktian. Pandangan salah yang 
berlaku selama ini ialah anak yang berjalan-jalan atau aktif selama kebaktian mengganggu ketertiban sehingga disuruh diam.

\section{- Bagi Sekolah}

Relasi sosial semakin luas karena anak mulai mengenal pendidikan formal baik di Play Group maupun Taman Kanak-kanak. Pengenalan lingkungan sekolah dengan guru, teman dan suasana baru dapat mendorong pengembangan inisiatif bila anak mendapat dukungan. Sebaliknya perasaan bersalah bisa mendominasi bila anak tidak diberi kesempatan untuk menguji kemampuannya.

\section{Bagi Anak Usia 6-12 Tahun}

a. Manfaat bagi Pendidikan Keluarga

- Keaktifan anak untuk mencapai keberhasilan dalam bidang akademis dan berbagai keterampilan sosial diperoleh melalui proses peniruan dari perilaku orang dewasa. Dalam segala hal orangtua berperan sebagai model untuk memberi teladan (Ef. 6:4).

- Orangtua dapat mengikutsertakan anak dalam kursus tertentu berkaitan dengan bakat dan minat mereka sebagai usaha mengembangkan kompetensinya, tentu waktu relaksasi perlu diperhatikan.

- Pentingnya pendampingan orangtua pada saat anak melihat tayangan TV atau info berbagai media sehingga anak meneladani model yang benar.

b. Manfaat Bagi Pendidikan di Gereja

Menciptakan interaksi yang baik antara anak dengan guru dan teman-teman di Sekolah Minggu sebagai wadah kelompok tumbuh bersama.

c. Manfaat Bagi Pendidikan di Sekolah

$\checkmark$ Penyusunan kurikulum yang memotivasi anak untuk percaya dengan kemampuannya seperti penerapan metode Cara Belajar Siswa Aktif (CBSA) yang memacu kerja aktif anak serta menumbuhkan kompetisi sehat dalam kelompoknya.

Peran guru bagi anak yang rendah diri ialah sebagai pendukung

\section{Bagi Usia 12-20 Tahun}

a. Manfaat Bagi Keluarga

- Identitas seks adalah isu penting yang dapat diatasi melalui figur ayah dan ibu dengan peran yang jelas. Orangtua adalah model pertama yang mempengaruhi identifikasi anak menjadi feminin atau maskulin. Pentingnya orangtua menjelaskan pendidikan seks mencegah anak memperoleh informasi yang tidak tepat yang dapat membawa anak dalam pergaulan dan pengalaman seks yang membahayakan. 
- Orangtua dapat memposisikan diri sebagai teman bagi remaja yang sedang berpetualang menemukan jati diri. Pemahaman orangtua sebagai teman diskusi membantu anak dalam menjalani masa transisi menuju kedewasaan.

b. Manfaat Bagi Pendidikan di Gereja

- Topik-topik penting berkaitan dengan pelayanan pada remaja ialah menanamkan dasar harga diri yang benar bahwa mereka berharga bukan atas pengakuan orang lain tetapi karena Allah mengasihi mereka (Ul. 32:10; Yes. 43:4a; Yoh. 3:16; I Pet. 2:24), pentingnya menjaga kesucian hidup (Kolose 3:5-10), kejelian memilih kelompok pergaulan (I Kor. 15:33).

- Pembimbing rohani berperan menjadi teman bagi remaja melalui program pelayanan yang sesuai dengan dunia mereka seperti Bible Camp, Mission Trip, Kompetisi Olahraga atau Musik.

c. Manfaat Bagi Pendidikan di Sekolah

Penyusunan kurikulum diarahkan kepada merangsang cara berpikir remaja yang menghadapi perubahan dunia sangat cepat melalui metode diskusi, pola belajar paduan pedagodi dan andragogi, atau pembahasan materi yang aktual.

\section{Bagi Pembinaan Usia Dewasa}

\section{- Dewasa Awal (20-40 tahun)}

a. Gereja mengupayakan pembimbingan keluarga berkaitan dengan beberapa pokok seperti: Pemilihan Teman Hidup, Kehidupan PASUTRI Muda, maupun topik Membina Keluarga Bahagia. Menyusun dan melaksanakan program tertentu bagi keluarga dimana orangtua dan anak menikmati kebersamaan dalam persekutuan rohani, misalnya: Family Day, Bulan atau Pekan Keluarga, dll, demi menjawab keintiman yang dibutuhkan.

b. Usia produkif seseorang pada tahap ini tepat dimotivasi untuk terlibat dalam pelayanan baik di gereja maupun melalui profesi mereka. Pentingnya komitmen kasih kepada Tuhan perlu disampaikan untuk mendorong keterlibatan seseorang dalam melayani.

c. Agen sosial terpenting pada tahap ini ialah sahabat, kekasih, suami atau isteri serta keluarga. Pendidikan Kristen berfungsi memotivasi setiap orang untuk setia kepada komitmen mereka terhadap pasangannya (Ef. 5:25-29) mengingat banyaknya keluarga yang mengalami keretakan karena perselingkuhan dan ketidaksiapan menghadapi terpaan hidup. Konseling Pra dan Pasca Nikah sangat 
membantu setiap keluarga untuk menghidupkan kasih sebagai kekuatan yang perlu ditumbuhkan terus-menerus menghadapi krisis keterasingan.

d. Menyusun dan melaksanakan program tertentu bagi keluarga dimana orangtua dan anak menikmati kebersamaan dalam persekutuan rohani, misalnya: Family Day, Bulan atau Pekan Keluarga, dll.

\section{- Dewasa Tengah (40-65 tahun)}

a. Kehilangan orang-orang yang dikasihi karena kematian pasangan hidup, Post Power Syndrome, persaingan dengan generasi muda serta menurunnya produktivitas menjadi masalah yang perlu mendapat pembimbingan serius. Pentingnya kesadaran bahwa manusia mengalami penurunan jasmani dan psikis, tetapi relasi akrab dengan Allah menyanggupkan usia ini menghadapi krisis hidup (Maz. 92:13-16; Maz. 37:5).

b. Selain tanggung jawab terhadap anak, orang dewasa pada tahap ini juga bertanggung jawab memelihara orangtua mereka yang berada pada tahap dewasa lanjut. Kepedulian sebagai kekuatan utama pada tahap ini dinyatakan dengan menghormati serta memelihara orangtua sebagai perintah yang disampaikan oleh Allah (Kel. 20:12; Ef. 6:1-3).

c. Menyikapi penurunan fungsi tubuh, gereja dapat mengadakan kegiatan seperti Senam Pagi, Tea Walk, Club Jantung Sehat dan sejenisnya yang juga menumbuhkan kepedulian antar anggota untuk mengatasi kejenuhan.

\section{- Dewasa lanjut (65 Tahun +)}

a. Gereja dapat mengisi keputusasaan pada usia ini dengan melibatkan para lansia dalam kegiatan gereja seperti pendoa syafaat, penasihat, perencana program dan keteladanan bagi generasi penerus (Titus 2:1-5). Keterlibatan melayani merupakan bentuk pemanfaatan positif dari waktu yang tersisa (Maz. 90:1-12; Ef. 5:16-17; Kol. 4:6).

b. Penurunan dan perubahan fisiologis serta psikologis memberi kesan masa ini seseorang kembali kekanak-kanakan. Gereja perlu membina usia dewasa awal dan tengah untuk bisa memahami keadaan mereka serta memberikan dukungan yang berarti.

c. Memotivasi para lansia dalam pembaharuan relasinya yang lebih bersifat pribadi kepada Tuhan (Maz. 71:1-24) serta menyiapkan mereka menghadapi kematian dengan meyakinkan adanya jaminan keselamatan di dalam Kristus (II Kor. 4:1610; I Tes. 4:13-18). 


\section{Kepustakaan}

Erik H. Erikson. Identitas dan Siklus Hidup Manusia, Jakarta:Penerbit Gramedia, 1989 Losoncy, Lawrence J. Religious Education and the Life-cycle. Catecethical Communication. Monk, F.J., AMP Knoers \& S.R. Hadinoto. Psikologi Perkembangan, Gadjah Mada University Press.

Sidjabat, B. Samuel. Pendewasaan Manusia Dewasa, Bandung: Institut Alkitab Tiranus, 2003 Wilhoit, James C., Deuttoni, John M. Nurture That Is Christian, A Bridgepoint Book. 